\title{
Self-efficacy dan mental toughness: Apakah faktor psikologis berkorelasi dengan performa atlet?
}

\author{
Edi Setiawan $^{1}$ *, Ihsan Abdul Patah ${ }^{1}$, Céu Bapista ${ }^{2}$, M.E Winarno ${ }^{3}$, Bebiana Sabino ${ }^{4}$, \\ Eneng Fitri Amalia ${ }^{1}$ \\ ${ }^{1}$ Universitas Suryakancana. Jl. Pasir Gede Raya, Cianjur, Jawa Barat, 43216, Indonesia \\ ${ }^{2}$ National University of Timor Lorosa'e. Av. Cidade de Lisboa, Díli, Timor-Leste \\ ${ }^{3}$ Universitas Negeri Malang. J1. Semarang 5, Malang, 65145, Indonesia \\ ${ }^{4}$ Polytechnic Institute of Beja. R. $1^{\circ}$ de Maio, 7800-000 Beja, Portugal \\ * Corresponding Author. Email: edisetiawan@student.upi.edu
}

Received: 27 July 2020; Revised: 13 August 2020; Accepted: 18 August 2020

\begin{abstract}
Abstrak: Faktor psikologis saat ini telah menjadi salah satu aspek yang sangat penting dalam olahraga futsal, namun belum diketahui dengan jelas faktor mana yang lebih berkorelasi dengan performa. Tujuan penelitian ini mencoba untuk menganalisis besarnya korelasi dua faktor psikologis antara self-efficacy dan mental toughness dengan performa atlet futsal. Pendekatan penelitian adalah kuantitatif dengan metode deskriptif korelasional. Subjek sebanyak tiga puluh atlet futsal amatir dari Suryakancana University (15 pria dan 15 wanita, $\mathrm{n}=30$ ). Instrumen self-efficacy, mental toughness dan performa menggunakan FSEQ, FMTQ dan $F P Q$. Analisis data menggunakan IBM SPSS software versi 25 dengan analisis korelasi person product moment dan analisis korelasi ganda. Hasil penelitian membuktikan bahwa terdapat korelasi yang signifikan antara self-efficacy dengan performa atlet, terdapat korelasi yang signifikan antara mental toughness dengan performa atlet, terdapat korelasi antara self-efficacy dan mental toughness dengan performa atlet dalam kategori tinggi diperoleh $(\mathrm{r}=0.733, \mathrm{Sig}=0.002<0.05)$. Kesimpulan dalam penelitian ini adalah terdapat korelasi yang tinggi antara self-efficacy dan mental toughness dengan performa atlet futsal.
\end{abstract}

Kata Kunci: Sport psychology, Self-efficacy, Mental toughness, Performa, Futsal

\section{Self-efficacy and mental toughness: Do psychological factors correlate with athlete performance?}

\begin{abstract}
Psychological factors have become one of the most important aspects in futsal, however it is not clear which factors are more correlated with performance. The purpose of this study is to analyze the magnitude of the correlation between two psychological factors between self-efficacy and mental toughness with the performance of futsal athletes. The research approach is quantitative with correlational descriptive methods. Thirty amateur athletes from Suryakancana University (15 men and 15 women, $n=30)$. Instrumen of self-efficacy, mental toughness and performance using FSEQ, FMTQ and FPQ. Data analysis using IBM SPSS software version 25 with Pearson Product Moment correlation analysis and multiple correlation analysis. The results found that there was a significant correlation between self-efficacy and athlete performance, there is a significant correlation between mental toughness with athlete performance, there is a correlation between self-efficacy and mental toughness with athlete performance in the high category $(r=0.733$, Sig=0.002 $<0.05)$. The conclusion in this study is that there is a high correlation between selfefficacy and mental toughness with the performance of futsal athletes.
\end{abstract}

Keywords: Sport psychology, Self-efficacy, Mental toughness, Performance, Futsal

How to Cite: Setiawan, E., Patah, I., Baptista, C., Winarno, M., Sabino, B., \& Amalia, E. (2020). Self-efficacy dan mental toughness: Apakah faktor psikologis berkorelasi dengan performa atlet?. Jurnal Keolahragaan, 8(2), 158-165. doi:https://doi.org/10.21831/jk.v8i2.33551

\section{PENDAHULUAN}

Futsal merupakan salah satu olahraga yang sangat populer dan berkembang dengan pesat saat ini, perkembangan itu terlihat dengan banyaknya remaja yang ingin menjadi atlet dalam olahraga futsal (Doğramac1 et al., 2017; Windoro et al., 2019). Data menunjukkan bahwa lebih dari 30 juta atlet futsal 
berasal dari 100 negara (Dogramaci et al., 2017). Data tersebut menjadi salah satu bukti bahwa futsal memang merupakan olahraga yang sangat digemari oleh para pemuda di seluruh dunia (Benvenuti et al., 2010). Perkembang-an olahraga futsal di Indonesia menunjukkan peningkatan sangat signifikan, hal itu dibuktikan dengan banyaknya pertandingan yang sering diadakan dari mulai tingkat daerah, nasional hingga internasional (Doğramacı et al., 2017; Windoro et al., 2019). Maka dari itu, untuk menjadi atlet yang professional di era futsal modern saat ini, harus memiliki performa yang baik. Apabila seorang atlet mempunyai performa yang baik, maka dapat melakukan gerakan passing, shooting dan dribbling dengan optimal, sehingga berpeluang untuk memenangkan pertandingan.

Psikologi olahraga telah menjadi bagian penting dari olahraga sepakbola (Sivrikaya, 2019), ataupun futsal dan menjadi faktor keberhasilan atau kegagalan bagi atlet saat bertanding. Temuan terdahulu menunjukkan bahwa aspek psikologi dalam olahraga dapat membantu meningkatkan performa atlet futsal (Newland et al., 2013). Fenomena saat ini, kebanyakan dari para atlet hanya fokus untuk mengembangkan aspek fisik, teknik dan taktik dan sering kali mengabaikan aspek psikologis (Harsono, 2015). Padahal aspek-aspek psikologis tersebut perlu dilatih dan dikembangkan dengan baik, karena dalam sebuah pertandingan, aspek psikologis memiliki pengaruh $80 \%$ dan lainnya adalah $20 \%$ (Aliyyah et al., 2020). Temuan penelitian lainnya juga melaporkan bahwa aspek psikologis berkontribusi lebih dari $50 \%$ terhadap keberhasilan atlet saat bertanding (Liew et al., 2019). Banyak sekali aspek psikologis seperti kepercayaan diri, self-efficacy, kosentrasi, motivasi, anxiety dan mental toughness, di mana semua aspek tersebut sangat mempengaruhi terhadap performa atlet saat latihan maupun bertanding (Zetou et al., 2012). Self-efficacy dan mental toughness merupakan dua faktor yang diperkirakan berpotensi untuk membantu meningkatkan performa atlet futsal.

LaForge-MacKenzie dan Sullivan (2014) mendefinisikan self-efficacy sebagai kemampuan seseorang untuk melakukan suatu tindakan dengan sebaik mungkin untuk mencapai suatu tujuan tertentu. Sedangkan Seseorang dengan self-efficacy yang tinggi adalah orang-orang yang mempunyai keyakinan bahwa mereka dapat melakukan sesuatu dengan baik, tugas-tugas sulit dapat dikuasai, bukan untuk dihindari. Self-efficacy telah dianggap sebagai elemen penting dari sebuah pelatihan mental (Zagórska \& Guszkowska, 2014) dan self-efficacy memainkan peran kunci dalam memicu timbulnya motivasi, sehingga kemampuan untuk melakukan satu serangkaian tugas gerak dapat lebih optimal (Stewart \& George-Walker, 2014). Atlet dengan self-efficacy lebih tinggi cenderung berusaha lebih keras, bertahan lebih lama dalam menghadapi sebuah tantangan, dan memicu timbulnya pola pikir yang positif (Barker \& Jones, 2008), serta dipercaya mampu mengurangi tingkat kecemasan (Mouloud \& Elkader, 2016). Banyak sekali penelitian terdahulu yang sudah dilakukan terkait dengan self-efficacy, seperti penelitian Cotterill et al. (2010) yang mengkaji hubungan self-efficacy dengan performa atlet dalam permainan sepak bola. Penelitian menganalisis dampak dari self-efficacy dengan tingkat kecemasan (Hazell et al., 2014). Kemudian penelitian LaForge-MacKenzie dan Sullivan (2014) menguji hubungan antara selfefficacy dan performa olahraga, hasilnya membuktikan bahwa korelasi antara self-efficacy dan performa olahraga dalam kategori sedang. Sulitnya menemukan literature pada studi sebelumnya yang mencoba untuk menganalisis dua aspek psikologis secara bersamaan antara self-efficacy dan mental toughness yang dikaitkan dengan performa atlet, inilah yang menjadi dasar mengapa penelitian ini penting untuk dilakukan.

Mental toughness memiliki banyak pengertian, namun secara umum mental toughness digambarkan dengan kemampuan seorang atlet secara konsisten berhasil mengatasi adversity (Setiawan et al., 2017), stres dan kecemasan di saat situasi kompetitif dan penuh tekanan (Weinberg et al., 2011). Selain itu, mental toughness dianggap sebagai faktor penting bagi atlet untuk menampilkan performa yang terbaik dalam sebuah pertandingan (Mahoney et al., 2014). Karakteristik seseorang yang memiliki mental toughness adalah mudah bergaul dan ramah, mampu tetap tenang walaupun kondisi sedang tertekan, mempunyai mental juara dan pemikiran yang optimis (Gucciardi \& Jones, 2012), memiliki tingkat motivasi yang tinggi (Connaughton et al., 2010) dan kecemasan yang lebih rendah daripada yang lain (Lin et al., 2017). Namun penelitian terdahulu melaporkan bahwa mental toughness belum dapat dipastikan berkorelasi dengan performa olahraga (Cowden, 2017).

Banyak kajian sebelumnya hanya meneliti hubungan dari masing-masing aspek psikologis tersebut secara terpisah dan jarang sekali ditemukan studi yang menganalisis korelasi secara bersamaan antara self-efficacy dan mental toughness dengan performa atlet futsal. Selain itu, korelasi antara self-efficacy dan mental toughness juga belum diketahui secara jelas dan bagaimana hal itu mempengaruhi performa atlet futsal. Oleh karena itu, tujuan dari penelitian ini adalah untuk menguji besarnya korelasi dua faktor 
psikologis (self-efficacy dan mental toughness) dengan performa atlet futsal. Peneliti berhipotesis bahwa dua faktor psikologis tersebut mempunyai korelasi yang tinggi dengan performa atlet futsal.

\section{METODE}

\section{Desain}

Jenis pendekatan dalam penelitian ini adalah kuantitatif dengan penggunaan metode deksriptif korelasional (Argudo-Iturriaga, 2020), dengan desain penelitian $\mathrm{RX}_{1}, \mathrm{X}_{2}, \mathrm{Y}$ merupakan sebuah desain untuk mencoba menganalisis koefisien korelasi dari setiap variabel yang digunakan, tujuan utama dari desain ini adalah untuk melihat besarnya korelasi antara variable independent $\left(\mathrm{X}_{1}, \mathrm{X}_{2}\right)$ dengan variable dependent $(\mathrm{Y})$.

\section{Subjek}

Tiga puluh mahasiswa dari Suryakancana University (Indonesia) (15 pria dan 15 wanita, $\mathrm{n}=30$ ) berpartisipasi dalam penelitian ini. Teknik pengambilan subjek menggunakan total sampling. Untuk karakteristik subjek (pria: usia $=20.33 \pm 1.11$ tahun, tinggi: $168.00 \pm 1.92 \mathrm{~cm}$ dan berat; $59.60 \pm 2.47 \mathrm{~kg}$, wanita: usia $=20.27 \pm 1.03$ tahun, tinggi $=157.27 \pm 2.21 \mathrm{~cm}$ dan berat $=53.60 \pm 2.13 \mathrm{~kg}$ ). Subjek dipilih dari atlet futsal dengan level amatir dari Universitas Suryakancana Cianjur.

\section{Instrumen}

Self-efficacy. Untuk mengukur tingkat self-efficacy atlet futsal memodifikasi dari Soccer SelfEfficacy Questionnaire (SSEQ) (Barker \& Jones, 2008), kemudian peneliti kembangkan secara khusus untuk olahraga futsal menjadi "Futsal Self-Efficacy Questionnaire (FSEQ)". Questionnaire ini terdiri dari 10 item pertanyaan yang berkaitan dengan keterampilan heading, keterampilan dribbling, pengambilan keputusan, kegigihan, konsentrasi, mengatasi tekanan, kegiatan pertandingan, keterampilan shooting, keterampilan passing, bertahan dan menyerang (Heazlewood \& Burke, 2011; Barker \& Jones, 2008). Sementara Bandura (1978) menganjurkan menilai tingkat, kekuatan, dan generalisasi keyakinan self-efficacy, FSEQ mengikuti pedoman menunjukkan bahwa ukuran self-efficacy dalam olahraga adalah tugas khusus dan menilai kekuatan self-efficacy. Untuk masing-masing dari 10 item ini, menggunakan skala Likert di mulai dari nilai 1 sangat tidak setuju (STS), 2 tidak setuju (TS), 3 kurang setuju (KS), 4 setuju (S) hingga 5 sangat setuju (SS) (Drinkwater et al., 2018). Skor berasal dari sepuluh pertanyaan yang dijumlahkan, sebagai skor akhir dari self-efficacy atlet futsal. Instrumen $F S E Q$ telah diujicoba terlebih dahulu kepada atlet futsal PORDA Kabupaten Cianjur sebanyak 20 orang dan hasil uji instrumen menunjukan validitas (0.754) dan reliabilitas (0.878).

Mental Toughness. Untuk mengukur tingkat mental toughness atlet futsal menggunakan questionnaire yang memodifikasi dari Mahoney et al. (2014) terdiri dari delapan item dari mental toughness (misalnya: saya bisa mengatur fokus saya saat bertanding). Namun peneliti kembangkan secara khusus untuk olahraga futsal menjadi "Futsal Mental Toughness Questionnaire (FMTQ)". Questionnaire ini memiliki lima item pertanyaan dalam skala likert dan dirancang untuk mengevaluasi mental toughness atlet futsal. Lima item tersebut terdiri dari "(1) saya bisa mengatur kosentrasi saat bertanding; (2) saya tidak akan terpengaruh oleh buly dari pemain dan suporter lawan; (3) saya bisa mengatasi perasaan stres dan kecemasan di saat situasi kompetitif dan penuh tekanan; (4) saya mampu bangkit walau dalam kondisi terpuruk; (5) saya mampu mengontrol emosi. Pertanyaan ini menggunakan skala Likert (mulai dari nilai 1 sangat tidak setuju (STS), 2 tidak setuju (TS), 3 kurang setuju (KS), 4 setuju (S) hingga 5 sangat setuju (SS) (Drinkwater et al., 2018). Skor berasal dari lima pertanyaan yang dijumlahkan, sebagai skor akhir dari mental toughness atlet futsal. Hasil uji instrumen FMTQ menunjukan validitas (0.811) dan reliabilitas (0.707).

Performa. Questionnaire ini dibuat pada tahun 2001 oleh Charbonneau untuk olahraga sepak bola (Sivrikaya, 2019), namun peneliti modifikasi secara khusus untuk olahraga futsal menjadi "Futsal Performance Questionnaire (FPQ)". Questionnaire ini memiliki lima pertanyaan dalam skala Likert dan dirancang untuk mengevaluasi performa atlet futsal. Lima pertanyaan terdiri dari passing, tackling, heading, ball control, decision-making. Skor yang diperoleh dari lima pertanyaan menunjukkan skor akhir dari performa atlet. Pertanyaan ini ada pada skala 1 (sangat buruk), 2 (buruk), 3 (sedang), 4 (istimewa), hingga 5 (sangat istimewa). Skor berasal dari lima pertanyaan yang dijumlahkan, sebagai skor akhir 
Edi Setiawan, Ihsan Abdul Patah, Céu Bapista, M.E Winarno, Bebiana Sabino, Eneng Fitri Amalia

dari performa atlet futsal (Barker \& Jones, 2008). Hasil uji instrumen FMTQ menunjukan validitas $(0.950)$ dan reliabilitas $(0.820)$.

\section{Prosedur}

Penelitian dilakukan pada tanggal 11 Juli 2020 dan penelitian ini telah disetujui oleh komite etika futsal lokal dari Universitas Suryakancana. Subjek diinstruksikan untuk menyelesaikan FSEQ, FMTQ dan $F P Q$, dengan diberikan waktu 15 menit untuk masing-masing instrumen. Pengisian questionnaire dilakukan di rumah atlet masing-masing dan di awasi oleh peneliti melalui zoom, cara ini dilakukan agar tidak terjadi kesalahan dalam pengisian questionnaire dan terhindar dari penularan coronavirus (COVID-19).

\section{Analisis Statistik}

Setelah data terkumpul dari hasil pengukuran, maka tahap selanjutnya menganalisis data tersebut menggunakan bantuan IBM SPSS software versi 25 . Untuk pengujian normalitas menggunakan ShapiroWilk test dan pengujian linieritas. Sedangkan analisis korelasi person product moment digunakan untuk melihat besarnya korelasi antara $\mathrm{X}_{1}$ dengan $\mathrm{Y}$, dan $\mathrm{X}_{2}$ dengan $\mathrm{Y}$, sedangkan analisis korelasi ganda digunakan untuk melihat besarnya korelasi secara bersama antara $\mathrm{X}_{1}, \mathrm{X}_{2}$ dengan $\mathrm{Y}$, dengan taraf signifikansi menggunakan $\alpha 0.05$.

\section{HASIL DAN PEMBAHASAN}

\section{Hasil}

Hasil pengujian normalitas self-efficacy (Sig 0.240), mental toughness (Sig 0.362) dan performa (Sig 0.459) dinyatakan normal, sedangkan hasil devitiation of linearity (Sig 0.132) artinya ada hubungan yang linier antara self-eficacy, mental toughness dengan performa. Untuk hasil pengujian hipotesis korelasi antara self-eficacy dengan performa atlet (lihat Tabel 1), korelasi mental toughness dengan performa atlet (lihat Tabel 2) dan korelasi self-efficacy dan mental toughness dengan performa atlet (Tabel 3).

Tabel 1. Korelasi Self-Efficacy dengan Performa Atlet

\begin{tabular}{ccccc}
\hline Variabel & $\mathrm{N}$ & $\mathrm{M} \pm \mathrm{SD}$ & Pearson Correlation & Sig. (2-tailed) \\
\hline Self-Eficacy dengan Performa Atlet & 30 & $69.20 \pm 15.35$ & $0.707 * *$ & 0.003 \\
\hline
\end{tabular}

Note: N: Subjek, M: Mean, SD: standard deviation

Berdasarkan Tabel 1 diperoleh nilai pearson correlation sebesar $(r=0.707, \mathrm{Sig}=0.003<0.05)$. Artinya terdapat korelasi yang signifikan antara self-efficacy dengan performa atlet, dan besarnya korelasi dalam kategori tinggi (Sugiyono, 2010).

Tabel 2. Korelasi Mental Toughness dengan Performa Atlet

\begin{tabular}{ccccc}
\hline Variabel & $\mathrm{N}$ & $\mathrm{M} \pm \mathrm{SD}$ & Pearson Correlation & Sig. (2-tailed) \\
\hline Mental Toughness dengan Performa Atlet & 30 & $48.13 \pm 19.39$ & $0.673^{* *}$ & 0.006 \\
\hline
\end{tabular}

\section{Note: N: Subjek, M: Mean, SD: standard deviation}

Berdasarkan Tabel 2 diperoleh nilai pearson correlation sebesar $(r=0.673$, Sig $=0.006<0.05)$. Artinya terdapat korelasi yang signifikan antara mental toughness dengan performa atlet, dan besarnya korelasi dalam kategori sedang (Sugiyono, 2010).

Tabel 3. Korelasi Self- Efficacy dan Mental Toughness dengan Performa Atlet

\begin{tabular}{ccccc|c}
\hline \multicolumn{6}{c}{ Model Summary } \\
\hline Model & $R$ & $R$ Square & Adjusted $R$ Square & Std. Error of the Estimate & Sig. (2-tailed) \\
1 & $0.733^{\text {a }}$ & 0.538 & 460 & 3.281 & 0.002 \\
\hline
\end{tabular}

a. Predictors: (Constant), $\mathrm{X}^{1}, \mathrm{X}^{2}$ dengan $\mathrm{Y}$

Berdasarkan Tabel 3 diperoleh nilai korelasi ganda antara self-eficacy dan mental toughness dengan performa atlet sebesar $(\mathrm{r}=0.733$, Sig $=0.002<0.05)$ dan $\mathrm{R}$ Square $=0.538$. Atinya bahwa besarnya korelasi dalam kategori tinggi (Sugiyono, 2010). 


\section{Pembahasan}

Korelasi self-efficacy dengan performa atlet

Dari hasil uji korelasi antara self-efficacy dengan performa atlet diperoleh $(r=0.707, \mathrm{Sig}=0.003$ $<0.05$ ), nilai tersebut menunjukkan bahwa terdapat korelasi yang signifikan di antara keduanya. Hasil studi sebelumnya pun membuktikan bahwa self-efficacy memang berpengaruh positif dengan performa atlet sepakbola (Barker \& Jones, 2008). Dengan demikian, dapat diartikan bahwa self-efficacy memang berpengaruh positif pada olahraga yang memiliki karakteristik permainan beregu yang kompetitif, seperti sepakbola maupun futsal. Penelitian LaForge-MacKenzie dan Sullivan (2014) melaporkan bahwa korelasi antara self-efficacy dan kinerja olahraga dengan kategori sedang. Studi lain menemukan bahwa selfefficacy dengan performa wasit dan hasilnya menunjukkan bahwa pengetahuan permainan dan keterampilan strategis, keterampilan membuat keputusan, komunikasi dan kontrol dalam game dari seorang wasit meningkat secara signifikan (Guillen \& Feltz, 2011; Karacam \& Pulur, 2017; Karacam \& Adiguzel, 2019). Selain itu, self-efficacy dalam olahraga, membuat keputusan yang lebih baik, menampilkan performa yang lebih efektif dan mengalami lebih sedikit stress dalam sebuah pertandingan. Hasil penelitian Hepler \& Feltz, (2014) melaporkan bahwa tingkat self-efficacy memiliki pengaruh signifikan terhadap pengambilan keputusan, yang memiliki efek positif pada kinerja wasit. Self-efficacy secara positif dapat memprediksi performa atlet dalam olahraga, seperti menyelam, senam, baseball, angkat besi, gulat, dan bola voli (Gilson et al., 2012). Dalam penelitian ini, self-efficacy dapat membuat performa atlet futsal menjadi lebih tinggi, seperti menyerang dan bertahan lebih baik, bahkan dalam melakukan teknis dan taktis menjadi lebih optimal (García-Naveira, 2018; Argudo-Iturriaga, 2020). Selain itu, kelebihan dari hasil penelitian ini terletak pada instrumen self-efficacy yang dimodifikasi khusus untuk olahraga futsal, sehingga hasil dari pengukuran lebih valid dan akurat. Dengan demikian, hasil penelitian ini menegaskan bahwa faktor psikologis self-efficacy berkorelasi tinggi dengan performa atlet pada olahraga futsal.

\section{Korelasi mental toughness dengan performa atlet}

Dari hasil uji korelasi antara mental toughness dengan performa atlet diperoleh ( $\mathrm{r}=0.673, \mathrm{Sig}=0.006$ $<0.05$ ), nilai tersebut menunjukan bahwa terdapat korelasi yang signifikan di antara keduanya. Mental toughness mampu mengurangi tingkat stress dan membuat performa lebih maksimal (Crust et al., 2014). Selain itu, hasil penelitian Haghighi dan Gerber (2019) menemukan bahwa tingkat mental toughness yang lebih tinggi, pada siswa sekolah menengah dan sarjana, dikaitkan dengan penurunan tingkat gejala depresi yang timbul akibat situasi tekanan. Secara emosional, individu yang tangguh secara mental mampu mengelola stress secara efektif (Lin et al., 2017). Mental toughness memang memberikan kontribusi terhadap performa dalam suatu olahraga, namun penelitian Cowden (2016) melaporkan kontribusi itu juga tergantung pada situasi tertentu, seperti situasi tertekan yang biasanya menimbulkan tingkat kecemasan menjadi tinggi, misalnya saat situasi melakukan tendangan penalti, tertinggal jumlah skor, tidak mampu memutus serangan lawan dan tidak mampu untuk mencetak goal, di saat situasi-situasi seperti itu faktor psikologis yaitu mental toughness sangat penting bagi atlet untuk menentukan tingkat keberhasilan (Cowden, 2017).

\section{Korelasi self-efficacy dan mental toughness dengan performa atlet}

Dari hasil uji korelasi ganda antara self-efficacy dan mental toughness dengan performa atlet diperoleh $(\mathrm{r}=0.733$, Sig $=0.002<0.05)$, nilai tersebut membuktikan bahwa kedua aspek psikologis antara selfefficacy dan mental toughness sangat berkaitan erat dengan kegiatan olahraga, khususnya dalam menampilkan performa yang terbaik dalam sebuah permainan futsal. Aspek self-efficacy yang tinggi akan membuat atlet mampu menampilkan performa yang lebih baik (Zetou et al., 2012), misalnya, shooting, dribbling, passing dengan optimal, mampu bertahan maupun menyerang dengan baik, mampu menciptakan pikiran positif pada diri atlet, dengan demikian self-efficacy merupakan salah satu aspek dalam psikologis yang berperan penting bagi keberhasilan atlet di sebuah pertandingan yang kompetitif (Cowden, 2016). Mental toughness yang tinggi membuat atlet mampu mengatasi stress maupun depresi saat bertanding, sehingga mental toughness dapat diakui sebagai salah satu prediksi untuk atlet menampilkan performa terbaiknya (Cowden, 2017). Oleh karena itu, hasil penelitian ini menegaskan bahwa faktor psikologis antara self-efficacy dan mental toughness akan mempegaruhi baik atau buruknya performa atlet futsal ketika bertanding. 


\section{SIMPULAN}

Penelitian ini membuktikan bahwa terdapat korelasi yang tinggi antara dua faktor psikologis (selfefficacy dan mental toughness) dengan performa atlet futsal. Oleh karena itu, seorang pelatih maupun atlet harus mulai memperhatikan serta mengembangkan kedua aspek tersebut sejak usia dini, sehingga atlet dapat menampilkan performa terbaiknya dalam sebuah pertandingan. Dalam penelitian ini masih terdapat limitasi, yaitu subjek yang digunakan relatif sedikit dan hanya mencakup satu daerah saja. Maka dari itu penelitian dimasa mendatang perlu dilakukan dengan menambahkan subjek penelitian lebih banyak dan berasal dari beberapa dari daerah di Indonesia.

\section{DAFTAR PUSTAKA}

Aliyyah, A., Wicaksono, B., Saniatuzzulfa, R., \& Mukholid, A. (2020). Relevance of self efficacy and female futsal athletes' anxiety before the match. Jurnal SPORTIF : Jurnal Penelitian Pembelajaran, 6(1), 105-117. https://doi.org/10.29407/js_unpgri.v6i1.14080

Argudo-Iturriaga, F. M., Alberti-Amengual, A., Borges-Hernández, P. J., \& Ruiz-Lara, E. (2020). Self-efficacy perception in elite water polo goalkeepers. Journal of Human Sport and Exercise, 16(2), 1-8. https://doi.org/10.14198/jhse.2021.162.06

Bandura, A. (1978). Self-efficacy: Toward a unifying theory of behavioral change. Advances in Behaviour Research and Therapy, 1(4), 139-161. https://doi.org/10.1016/0146-6402(78)900024

Barker, J. B., \& Jones, M. V. (2008). The effects of hypnosis on self-efficacy, affect, and soccer performance: A case study. Journal of Clinical Sport Psychology, 2(2), 127-147. https://doi.org/10.1123/jcsp.2.2.127

Benvenuti, C., Minganti, C., Condello, G., Capranica, L., \& Tessitore, A. (2010). Agility assessment in female futsal and soccer players. Medicina, 46(6), 415. https://doi.org/10.3390/medicina46060058

Connaughton, D., Hanton, S., \& Jones, G. (2010). The development and maintenance of mental toughness in the world's best performers. The Sport Psychologist, 24(2), 168-193. https://doi.org/10.1123/tsp.24.2.168

Cotterill, S. T., Sanders, R., \& Collins, D. (2010). Developing effective pre-performance routines in golf: Why don't we ask the golfer? Journal of Applied Sport Psychology, 22(1), 51-64. https://doi.org/10.1080/10413200903403216

Cowden, R. G. (2016). Competitive performance correlates of mental toughness in tennis. Perceptual and Motor Skills, 123(1), 341-360. https://doi.org/10.1177/0031512516659902

Cowden, R. G. (2017). Mental toughness and success in sport: A review and prospect. The Open Sports Sciences Journal, 10(1), 1-14. https://doi.org/10.2174/1875399X01710010001

Crust, L., Earle, K., Perry, J., Earle, F., Clough, A., \& Clough, P. J. (2014). Mental toughness in higher education: Relationships with achievement and progression in first-year university sports students. Personality and Individual Differences, 69(October), 87-91. https://doi.org/10.1016/j.paid.2014.05.016

Doğramac1, S. N., Watsford, M. L., \& Murphy, A. J. (2017). Activity profile differences between subelite futsal teams. International Journal of Exercise Science, 8(2), 112-123. https://digitalcommons.wku.edu/ijes/vol8/iss2/2/

Drinkwater, K., Dagnall, N., Denovan, A., \& Parker, A. (2019). The moderating effect of mental toughness: Perception of risk and belief in the paranormal. Psychological Reports, 122(1), 268287. https://doi.org/10.1177/0033294118756600

Gilson, T. A., Chow, G. M., \& Feltz, D. L. (2012). Self-efficacy and athletic squat performance: Positive or negative influences at the within- and between-levels of analysis. Journal of Applied Social Psychology, 42(6), 1467-1485. https://doi.org/10.1111/j.1559-1816.2012.00908.x

Gucciardi, D. F., \& Jones, M. I. (2012). Beyond optimal performance: Mental toughness profiles and developmental success in adolescent cricketers. Journal of Sport and Exercise Psychology, 34(1), 16-36. https://doi.org/10.1123/jsep.34.1.16 
Edi Setiawan, Ihsan Abdul Patah, Céu Bapista, M.E Winarno, Bebiana Sabino, Eneng Fitri Amalia

Guillén, F., \& Feltz, D. L. (2011). A conceptual model of referee efficacy. Frontiers in Psychology, 2(May 2014). https://doi.org/10.3389/fpsyg.2011.00025

Haghighi, M., \& Gerber, M. (2019). Does mental toughness buffer the relationship between perceived stress, depression, burnout, anxiety, and sleep? International Journal of Stress Management, 26(3), 297-305. https://doi.org/10.1037/str0000106

Harsono, Y. M. (2015). Developing learning materials for specific purposes. Teflin Journal, 18(2), 169-179. https://doi.org/http://dx.doi.org/10.15639/teflinjournal.v18i2/169-179

Hazell, J., Cotterill, S. T., \& Hill, D. M. (2014). An exploration of pre-performance routines, selfefficacy, anxiety and performance in semi-professional soccer. European Journal of Sport Science, 14(6), 603-610. https://doi.org/10.1080/17461391.2014.888484

Heazlewood, I., \& Burke, S. (2011). Self-efficacy and its relationship to selected sport psychological constructs in the prediction of performance in ironman triathlon. Journal of Human Sport and Exercise, 6(2 (Suppl.)), 328-350. https://doi.org/10.4100/jhse.2011.62.14

Hepler, T. J., \& Feltz, D. L. (2012). Take the first heuristic, self-efficacy, and decision-making in sport. Journal of Experimental Psychology: Applied, 18(2), 154-161. https://doi.org/10.1037/a0027807

Karacam, A. (2019). Examining the relationship between referee performance and self-efficacy. European Journal of Educational Research, 8(1), 377-382. https://doi.org/10.12973/eujer.8.1.377

Karaçam, A., \& Pulur, A. (2017). Examining the relationship between referee self-efficacy and general self-efficacy levels of basketball referees in terms of certain variables. Journal of Education and Training Studies, 5(8), 37. https://doi.org/10.11114/jets.v5i8.2450

LaForge-MacKenzie, K., \& Sullivan, P. J. (2014). The relationship between self-efficacy and performance within a continuous educational gymnastics routine. International Journal of Sport and Exercise Psychology, 12(3), 206-217. https://doi.org/10.1080/1612197X.2014.909511

Liew, G. C., Kuan, G., Chin, N. S., \& Hashim, H. A. (2019). Mental toughness in sport. German Journal of Exercise and Sport Research, 49(4), 381-394. https://doi.org/10.1007/s12662-01900603-3

Lin, Y., Clough, P. J., Welch, J., \& Papageorgiou, K. A. (2017). Individual differences in mental toughness associate with academic performance and income. Personality and Individual Differences, 113(July), 178-183. https://doi.org/10.1016/j.paid.2017.03.039

Mahoney, J. W., Gucciardi, D. F., Ntoumanis, N., \& Mallet, C. J. (2014). Mental toughness in sport: Motivational antecedents and associations with performance and psychological health. Journal of Sport and Exercise Psychology, 36(3), 281-292. https://doi.org/10.1123/jsep.2013-0260

Mouloud, K., \& Elkader, B. A. (2016). Self-efficacy and achievement motivation among football player. The Swedish Journal of Scientific Research, 3(11), 13-19. https://sjsr.se/en/downloads/articles/62/sjsr-03-(03-11).pdf

Naveira, A. G. (2018). Autoeficacia y rendimiento en jugadores de fútbol. Cuadernos De Psicología Del Deporte, 18(2), 66-78. https://revistas.um.es/cpd/article/view/319341

Newland, A., Newton, M., Finch, L., Harbke, C. R., \& Podlog, L. (2013). Moderating variables in the relationship between mental toughness and performance in basketball. Journal of Sport and Health Science, 2(3), 184-192. https://doi.org/10.1016/j.jshs.2012.09.002

Setiawan, E., Juliantine, T., \& Komarudin, K. (2017). Development creativity students through problem based learning model in physical education in reviewed of adversity quotient. 2nd International Conference on Sports Science, Health and Physical Education, 611-613. https://doi.org/10.5220/0007066606110613

Sivrikaya, M. H. (2019). The role of psychological hardiness on performance of scissors kick. Journal of Education and Training Studies, 6(12a), 70. https://doi.org/10.11114/jets.v6i12a.3932

Stewart, M. A., \& De George-Walker, L. (2014). Self-handicapping, perfectionism, locus of control and self-efficacy: A path model. Personality and Individual Differences, 66, 160-164. https://doi.org/10.1016/j.paid.2014.03.038 
Edi Setiawan, Ihsan Abdul Patah, Céu Bapista, M.E Winarno, Bebiana Sabino, Eneng Fitri Amalia

Sugiyono. (2010). Metode penelitian kuantitatif kualitatif dan $R \& D$. Alfabeta.

Weinberg, R., Butt, J., \& Culp, B. (2011). Coaches' views of mental toughness and how it is built. International Journal of Sport and Exercise Psychology, 9(2), 156-172. https://doi.org/10.1080/1612197X.2011.567106

Windoro, D., Kristiyanto, A., \& Riyadi, S. (2019). Decision making tactics of indonesian futsal women goalkeepers. International Journal of Advances in Social and Economics, 2(2). https://doi.org/10.33122/ijase.v2i2.152

Zagórska, A., \& Guszkowska, M. (2014). A program to support self-efficacy among athletes. Scandinavian Journal of Medicine \& Science in Sports, 24(3), e121-e128. https://doi.org/10.1111/sms.12125

Zetou, E., Vernadakis, N., Bebetsos, E., \& Makraki, E. (2012). The effect of self-talk in learning the volleyball service skill and self-efficacy improvement. Journal of Human Sport and Exercise, 7(4), 794-805. https://doi.org/10.4100/jhse.2012.74.07 